\title{
PREFERENSI KONSUMEN TERHADAP "PRIVATE LABEL" RITEL MODERN DIKAITKAN DENGAN KARAKTERISTIK KONSUMEN: STUDI KASUS PADA PRODUK GULA DI LOTTE MART BANDUNG
}

\author{
CONSUMER PREFERENCES TOWARDS MODERN RETAIL "PRIVATE LABEL" \\ ASSOCIATED WITH CONSUMER CHARACTERISTICS: \\ A CASE STUDY ON SUGAR PRODUCTS IN LOTTE MART BANDUNG
}

\author{
Elly Rasmikayati ${ }^{1}$, Siti Tari Syamsiah ${ }^{1}$, Agriani Hermita Sadeli ${ }^{1}$, Bobby Rachmat \\ Saefudin*2
}

${ }^{1}$ Fakultas Pertanian, Universitas Padjadjaran, Jl. Ry Bandung-Sumedang KM.21 Jatinangor, 45363

${ }^{2}$ Fakultas Pertanian, Ma'soem University, Jl. Raya Cipacing No. 22 Jatinangor, 45363

*E-mail corresponding: bobbyrachmat@masoemuniversity.ac.id

(Diterima 10-1-2021; Disetujui 18-1-2021)

\begin{abstract}
ABSTRAK
PT Lotte Mart Shopping Indonesia Bandung sebagai salah satu ritel modern di Kota Bandung, memiliki sejumlah produk dengan private label diantarnya produk gula. Penelitian ini bertujuan untuk menganalisis keterkaitan antara karakteristik konsumen dengan preferensi konsumen terhadap private label produk gula pada ritel modern Lotte Mart Shopping Indonesia Bandung. Responden penelitian sebanyak 42 responden yang merupakan konsumen private label produk gula di Lotte Mart yang ditentukan menggunakan teknik systematic random sampling. Alat analisis data yang dugunakan adalah tabulasi silang (crosstabs). Hasil penelitian preferensi konsumen menunjukkan bahwa atribut ukuran yang paling ideal menurut para responden adalah ukuran gula sebesar $1 \mathrm{~kg}$, desain kemasan gula private label sudah dikatakan menarik untuk merek Choice L, kejelasan informasi yang ada masih dikatakan kurang jelas dikarenakan informasi tentang produk tidak diperlihatkan secara jelas sehingga harus benar-benar memperhatikan kemasan dari produk tersebut. Atribut harga dan kemudahan dalam memperoleh produk gula merupakan faktor utama konsumen membeli produk gula dengan private label ini. Konsumen yang memiliki preferensi baik terhadap private label gula umumnya berjenis kelamin perempuan, berusia 36-50 tahun, berpendidikan SMA, pekerjaan sebagai ibu rumah tangga dengan pendapatan Rp. 2.000.000-Rp. 4.000.000 per bulan.
\end{abstract}

Kata kunci: preferensi konsumen, private label, gula pasir, karakteristik konsumen, ukuran, desain kemasan, akses, kualitas pelayanan

\begin{abstract}
PT Lotte Mart Shopping Indonesia Bandung, as one of the modern retailers in Bandung, has a number of products with private label, including sugar products. This study aims to analyze the relationship between consumer characteristics and consumer preferences for "private label" of sugar products at modern retailers Lotte Mart Shopping Indonesia Bandung. There were 42 research respondents who were private label consumers of sugar products at Lotte Mart who were determined using systematic random sampling technique. The data analysis tool used is cross tabulation. The results of the consumer preference research show that the most ideal size attribute according to the respondents is a sugar size of $1 \mathrm{~kg}$, the private label sugar packaging design has been said to be attractive for the Choice L brand, the clarity of the information is still unclear because the information about the product is not shown clearly. so you have to really pay attention to the packaging of these products. The price attribute and the ease of obtaining sugar products are the main factors for consumers buying sugar products with this private label. Consumers who
\end{abstract}


have a good preference for private label sugar are generally female, aged 36-50 years, have high school education, work as housewives with an income of Rp. 2,000,000-Rp. 4,000,000 per month.

Keywords: consumer preferences, private label, granulated sugar, consumer characteristics, size, packaging design, access, service quality

\section{PENDAHULUAN}

Pertumbuhan bisnis ritel modern di Indonesia membuat persaingan di dunia ritel semakin berkembang. Hal ini menyebabkan para peritel harus mencari strategi-strategi agar dapat bersaing satu sama lain dan mempertahankan pelanggannya. Melihat fenomena tersebut, beberapa penjual eceran (retailer) di Indonesia mencoba untuk mengemas produk yang mereka jual dengan kemasan dan merek sendiri yang disebut dengan private label. Peritel meluncurkan produk private label untuk membedakan barang dagangannya dengan ritel yang lain.

Private label adalah merek yang dimiliki oleh peritel. Dimana peritel memiliki produk-produk dengan merek dari peritel itu sendiri. Merek adalah salah satu faktor yang dapat mempengaruhi perilaku pembelian pelanggan atauperilaku belanja konsumen karena keunikan dan produk yang dikemas secara khusus. Private label ini hanya diproduksi oleh retailer menengah dan retailer besar saja. Private label dapat ditentukan sebagai label sendiri atau merek dari sebuah ritel seperti dicatat oleh Huang dan Huddleston (2009) dalam Abdullah (2012). Sebuah merek yang baik harus mampu memberikan citra produk kepada pelanggan dan memiliki nilai tambah di dalamnya.

Saat ini private label berkembang sangat pesat. Sejumlah ritel modern seperti hypermarket dan minimarket berlomba-lomba meluncurkan produk dengan merek sendiri (private label). Sebutlah Carrefour Indonesia, saat ini telah memiliki 2-3 ribu item produk private label dari total 40 ribu item produknya. Bahkan, minimarket seperti Indomaret saja telah memiliki sekitar 500 item produk dengan merek tokonya, disusul Alfamart yang diperkirakan memiliki 100 produk private label.

Sebagai salah satu ritel modern di Kota Bandung, PT Lotte Mart Shopping Indonesia Bandung memiliki sejumlah produk dengan private label diantaranya produk gula. Produk gula private label yang diproduksi oleh Lotte Mart sendiri ini terdiri atas beberapa merek, yaitu Jempol merupakan gula private label 
dengan ukuran yang lebih besar dari gula biasanya yaitu $3 \mathrm{~kg}$ yang dijual dengan harga terjangkau dengan tageline "Lebih Banyak Lebih Hemat". Kemudian terdapat gula private label bermerek Choice L, dimana makna dari merek ini adalah agar konsumen dapat memilih produk gula dengan kualitas dan harga yang sama dengan national brand yang berukuran $1 \mathrm{~kg}$. Save $L$ merupakan merek produk dengan kemasan $1 \mathrm{~kg}$ yang menawarkan harga dibawah pasar.

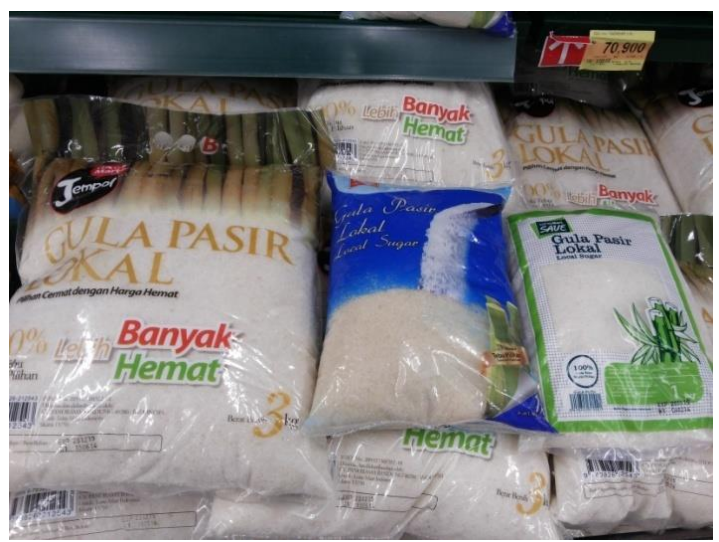

Gambar 1. Produk Gula Private label di Lotte Mart Bandung (Jempol, Choice L, dan Save L)

Sumber: Dokumentasi Peneliti

Gula sendiri termasuk dalam produk sehari-hari, menurut Daryanto (2011) dimana produk sehari-hari merupakan barang atau jasa yang biasa dibeli pelanggan dalam frekuensi tinggi, dalam waktu cepat dan untuk memperolehnya tidak membutuhkan upaya terlalu banyak. Perusahaan memberikan pilihan bagi konsumen yang ingin membeli gula private label dengan tiga merek yang berbeda memiliki keunggulan dan keunikan masing-masing (Gambar 1). Dengan bahan baku yang berkualitas sama dengan national brand dan ditawarkan dengan harga lebih terjangkau membuat produk gula private label di Lotte Mart ini berbeda dengan gula private label dari ritel modern lain. Gula private label ini tidak hanya dikeluarkan untuk dikonsumsi oleh kalangan menengah ke atas, akan tetapi dapat juga dinikmati oleh kalangan menengah ke bawah.

Meski berhasil mendatangkan kepercayaan yang instan dari konsumennya serta menawarkan harga yang lebih murah, ternyata private label tidak selamanya berhasil meyakinkan konsumen. Kenyataannya, produk yang diberi label merek toko itu sebenarnya tidak melampaui level 10\% dari seluruh produk yang dijual. Penelitian ini bertujuan untuk menganalisis keterkaitan antara karakteristik konsumen dengan preferensi konsumen terhadap "private label" produk gula pada ritel modern Lotte Mart Shopping Indonesia Bandung. 


\section{METODE PENELITIAN}

\section{Objek dan Tempat Penelitian}

Objek dari penelitian ini adalah karakteristik konsumen dengan preferensi konsumen terhadap "private label" produk gula ritel modern. Tempat penelitian dilakukan di Lotte Mart Shopping Indonesia Bandung. Tempat penelitian dipilih secara purposive (sengaja) dengan pertimbangan bahwa Lotte Mart merupakan salah satu gerai berformat ritel modern yang cukup lama masuk ke Indonesia dan telah memiliki konsumen yang cukup banyak.

\section{Desain Penelitian}

Desain penelitian yang digunakan adalah desain kualitatif deskriptif. Sedangkan teknik penelitian yang digunakan adalah studi kasus. Menurut Sugiyono (2010), studi kasus merupakan pengujian secara rinci terhadap satu latar atau satu orang subjek atau satu tempat penyimpanan dokumen atau satu peristiwa tertentu. Studi kasus bisa dilakukan kepada individu ataupun suatu kelompok, tujuan dari penelitian studi kasus adalah mengetahui suatu masalah secara mendalam.

\section{Variabel Penelitian}

Variabel-variabel dalam penelitian ini adalah preferensi konsumen dan karakteristik konsumen. Preferensi konsumen ditentukan oleh beberapa atribut yang mempengaruhi konsumen untuk membeli produk tersebut, diantaranya adalah ukuran, desain kemasan, kejelasan informasi pada produk, kemudahan memperoleh produk, harga, dan kualitas pelayanan. Sedangkan variabel karakteristik konsumen terdiri atas atribut jenis kelamin, usia, pendidikan, pekerjaan dan pendapatan.

\section{Jenis dan Sumber Data}

Data yang digunakan dalam penelitian ini adalah data primer dan data sekunder. Sumber data primer diperoleh dengan melakukan wawancara langsung terhadap 42 responden yang merupakan konsumen private label produk gula di Lotte Mart yang ditentukan menggunakan teknik systematic random sampling dengan interval 3 kedatangan. Sumber data sekunder diperoleh dari data-data melalui penelusuran buku, karya-karya ilmiah, internet, dan lembaga atau instansi yang berhubungan dengan topik penelitian yang dikaji.

\section{Rancangan Analisis Data}

Data dan informasi yang terkumpul diolah dan dianalisis secara kualitatif dan didukung oleh analisis secara kuantitatif. Untuk mengetahui bagaimana strategi 
pemasaran private label ritel modern adalah dengan menggunakan alat analisis tabulasi silang (crosstabs) adalah metode analisis yang paling sederhana tetapi memiliki daya menerangkan cukup kuat untuk menjelaskan hubungan antar variabel. Untuk itu ada beberapa prinsip sederhana yang perlu diperhatikan dalam menyusun tabel silang agar hubungan antara variabel tampak dengan jelas.

\section{HASIL DAN PEMBAHASAN}

\section{Preferensi Konsumen terhadap Produk Gula Private label Dikaitkan dengan Karakteristik Konsumen}

\section{Atribut Ukuran Produk Gula} Private label

Ukuran merupakan sebuah kuantitas yang terkandung di dalam sebuah produk (Rasmikayati dkk., 2020). Berdasarkan hasil wawancara mengenai preferensi konsumen terhadap atribut ukuran gula private label, sebanyak $74 \%$ konsumen mengaku ukuran dari gula private label tersebut sudah cukup praktis dan pas yaitu tidak terlalu banyak dan tidak terlalu sedikit, sedangkan sebanyak $26 \%$ mengaku bahwa ukuran gula private label tidak sesuai.

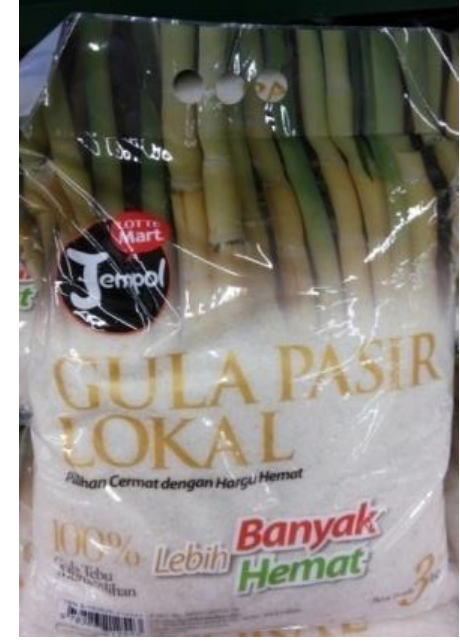

Gambar 2. Ukuran gula private label Jempol $3 \mathrm{~kg}$

Hal ini dikarenakan gula private label yang bermerek Jempol yaitu yang berukuran $3 \mathrm{~kg}$ dinilai terlalu besar sehingga tidak memudahkan untuk menyimpannya. Mereka menyatakan membeli gula Jempol tersebut dikarenakan harganya lebih murah dibanding membeli gula yang berukuran 1 kg dan juga karena kebutuhan konsumsi yang cukup banyak sehingga membelinya.

Pada persilangan karakteristik konsumen jenis kelamin dengan atribut ukuran responden yang menjawab ukuran dari gula private label ini sudah sesuai lebih didominasi oleh responden perempuan dengan jumlah 25 orang dan responden laki-laki dengan jumlah enam orang. Sedangkan responden yang menjawab atribut ukuran ini tidak sesuai berjumlah lima orang responden dengan 
jenis kelamin perempuan dan enam orang responden yang berjenis kelamin lakilaki.

Tabel 1. Tabulasi Silang Karakteristik Konsumen dengan Preferensi Konsumen terhadap Atribut Ukuran Kemasan Produk Gula Private label

\begin{tabular}{|c|c|c|c|}
\hline \multirow{2}{*}{$\begin{array}{l}\text { Variabel Karakteristik } \\
\text { Konsumen }\end{array}$} & \multicolumn{2}{|c|}{$\begin{array}{l}\text { Ukuran } \\
\text { Kemasan }\end{array}$} & \multirow{2}{*}{ Total } \\
\hline & \multirow[t]{2}{*}{ Sesuai } & $\begin{array}{l}\text { Tidak } \\
\text { Sesuai }\end{array}$ & \\
\hline \multicolumn{3}{|l|}{ Jenis Kelamin } & \\
\hline Laki-laki & 6 & 6 & 12 \\
\hline perempuan & 25 & 5 & 30 \\
\hline Total & 31 & 11 & 42 \\
\hline \multicolumn{4}{|l|}{ Usia } \\
\hline $19-24$ & 1 & 1 & 2 \\
\hline $25-35$ & 8 & 6 & 14 \\
\hline $36-50$ & 17 & 1 & 18 \\
\hline $51-65$ & 4 & 2 & 6 \\
\hline$>65$ & 1 & 1 & 2 \\
\hline Total & 31 & 11 & 42 \\
\hline \multicolumn{4}{|l|}{ Pendidikan } \\
\hline $\mathrm{SD}$ & 2 & 0 & 2 \\
\hline SMP & 4 & 2 & 6 \\
\hline SMA & 14 & 2 & 16 \\
\hline Diploma & 6 & 4 & 10 \\
\hline Sarjana & 5 & 3 & 8 \\
\hline Total & 31 & 11 & 42 \\
\hline \multicolumn{4}{|l|}{ Pekerjaan } \\
\hline PNS/Pegawai Swasta & 8 & 6 & 14 \\
\hline Pelajar/Mahasiswa & 1 & 1 & 2 \\
\hline Ibu Rumah Tangga & 20 & 3 & 23 \\
\hline Lainnya & 2 & 1 & 3 \\
\hline Total & 31 & 11 & 42 \\
\hline \multicolumn{4}{|l|}{ Pendapatan } \\
\hline < Rp. 2.000 .000 & 2 & 2 & 4 \\
\hline $\begin{array}{l}\text { Rp. } 2.000 .000-R p . \\
4.000 .000\end{array}$ & 25 & 8 & 33 \\
\hline > Rp. 4.000 .000 & 4 & 1 & 5 \\
\hline Total & 31 & 11 & 42 \\
\hline
\end{tabular}

Berdasarkan hasil wawancara para responden yang berusia 25-35 tahun menyatakan bahwa ukuran gula dengan merek Jempol terlalu besar sehingga menyulitkan konsumen untuk menyimpannya. Mereka mengaku membeli produk dengan merek Jempol ini dikarenakan harga yang lebih murah dengan jumlah yang banyak. Menurut Kotler and Armstrong (2008), keputusan pembelian konsumen terhadap suatu produk dipengaruhi oleh usia.

Pada hasil persilangan antara karakteristik konsumen pendidikan dengan preferensi konsumen terhadap atribut ukuran, dimana mayoritas responden yang menjawab ukuran dari produk gula ini sudah sesuai merupakan konsumen dengan tingkat pendidikan akhir SMA sebanyak 14 orang, SMP sebanyak empat orang, Diploma sebanyak enam orang, Sarjana sebanyak lima orang, dan SD sebanyak dua orang. Berdasarkan Rasmikayati dkk. (2020), tingkat pendidikan konsumen berpengaruh nyata terhadap tingkat kepuasan konsumen pada ritel modern.

Sedangkan untuk responden yang menjawab bahwa ukuran ini tidak sesuai adalah responden dengan pendidikan Diploma sebanyak empat orang, Sarjana sebanyak tiga orang, SMP dan SMA masing-masing sebanyak dua orang, dan tidak terdapat responden dengan pendidikan SD. Cara berpikir seseorang yang berpendidikan relatif lebih tinggi dan cenderung lebih maju dibandingkan 
tingkat pendidikan yang lebih rendah (Kotler and Armstrong, 2008).

Jenis pekerjaan juga bisa berpengaruh pada perilaku seseorang menyikapi suatu masalah. Sebanyak 20 orang ibu rumah tangga menyatakan ukuran produk ini sesuai, sedangkan para responden yang bekerja sebagai PNS/pegawai swasta mengaku bahwa menurut mereka produk gula private label yang bermerek Jempol ini ukurannya tidak sesuai karena jumlah anggota mereka yang sedikit sehingga seperti yang dijelaskan sebelumnya produk bermerek Jempol ini sulit untuk disimpan mengingat ukurannya yang sebesar $3 \mathrm{~kg}$.

Tingkat pendapatan secara langsung akan mempengaruhi daya beli konsumen (Rasmikayati dkk., 2020). Hal ini terlihat dimana tingkat pendapatan bagi konsumen yang menjawab ukuran dari produk ini sesuai didominasi oleh responden dengan pendapatan $\mathrm{Rp}$ 2.000.000 - Rp 4.000.000 sebanyak 25 orang, terdapat responden dengan tingkat pendapatan sebanyak lebih dari Rp 4.000.000 sebanyak empat orang dan kurang dari Rp 2.000.000 sebanyak dua orang.

Sedangkan untuk responden yang menjawab ukuran gula ini tidak sesuai adalah dari responden yang memiliki pendapatan Rp 2.000.000-Rp4.000.000 sebanyak delapan orang, lebih dari $\mathrm{Rp}$ 4.000.000 sebanyak satu orang, juga terdapat dua orang responden yang memiliki pendapatan dibawah $\mathrm{Rp}$ 2.000.000. Salah satu responden menyebutkan alasan yang sama bahwa kelemahan dari gula merek Jempol ini adalah ukurannya terlalu besar sehingga sulit untuk disimpan.

\section{Desain Kemasan Produk Gula Private label}

Kemasan adalah bentuk fisik yang dapat dilihat pertama kali dari sebuah produk. Desain kemasan juga menggambarkan keterangan dari sebuah produk yang dapat dilihat oleh konsumen (Deaniera dkk., 2020). Kemasan dari suatu produk dirancang sedemikian rupa dengan berbagai tujuan yang digunakan perusahaan untuk menarik konsumen sebanyak-banyaknya. Tujuan penggunaan kemasan antara lain adalah sebagai pelindung isi dari sebuah produk, juga sebagai identitas dari sebuah produk.

Pada persilangan antara karakteristik konsumen jenis kelamin dengan preferensi konsumen terhadap atribut desain kemasan. Dimana terdapat 19 responden perempuan dan enam responden laki-laki yang menjawab 
bahwa desain kemasan produk gula private label ini menarik. Sedangkan tedapat sebelas orang responden perempuan dan enam orang responden laki-laki menjawab bahwa desain kemasan ini tidak menarik. Hal ini menunjukkan bahwa karakteristik individu perempuan lebih peka terhadap suatu tampilan produk sedangkan lakilaki tidak terlalu memperhatikan kemasan tersebut. Menurut Peter \& Olson (2014) perempuan dapat memproses informasi yang berbeda dari pria dan tampak lebih murah hati dan lebih perhatian.

Pada Gambar 3 dapat dilihat salah satu contoh perbandingan produk gula private label Choice $L$ jenis stickpack atau gula sachet dengan desain kemasan produk pesaing Gulaku jenis stickpack. Dari desain kemasan ini produk pesaing menggunakan warna yang cerah dan memiliki gradiasi/pencampuran warna yang baik sehingga konsumen dapat mengatakan bahwa desain kemasan produk pesaing lebih menarik dibanding produk gula private label yang hanya menggunakan satu warna saja dan terkesan terlalu simple sehingga konsumen mudah bosan dengan kemasannya.
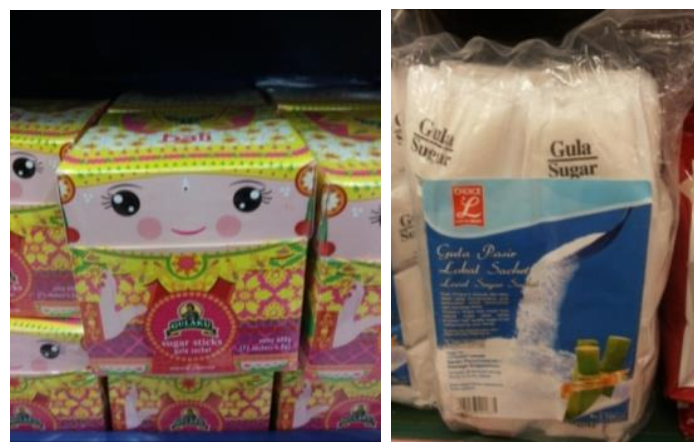

Gambar 3. Perbandingan Desain Kemasan Produk Pesaing dan Private label

$$
\text { Pada persilangan antara }
$$
karakteristik konsumen usia dengan preferensi konsumen terhadap atribut desain kemasan responden dengan jawaban menarik mayoritas berasal dari golongan usia 36-50 tahun sebanyak sepuluh orang, usia 25-35 tahun sebanyak tujuh orang, usia 51-65 tahun sebanyak enam orang, dan di atas 65 tahun sebanyak dua orang. Sedangkan untuk jawaban kurang menarik didominasi oleh responden dari golongan usia 36-50 tahun sebanyak delapan orang, dan usia 25-35 tahun sebanyak tujuh orang, juga terdapat usia 19-24 tahun sebanyak dua orang. Hal ini menunjukkan bahwa usia dewasa awal dan dewasa lanjut lebih peka terhadap suatu tampilan produk.

Menurut hasil wawancara responden yang mengatakan desain kemasan gula private label ini kurang menarik adalah responden yang membeli gula dengan merek Save L dan Jempol, karena modelnya yang tidak 
memunculkan kesan berkualitas juga kurang kreatif, sedangkan responden yang mengatakan bahwa desain kemasan ini menarik adalah kebanyakan responden yang membeli produk gula dengan merek Choice L.

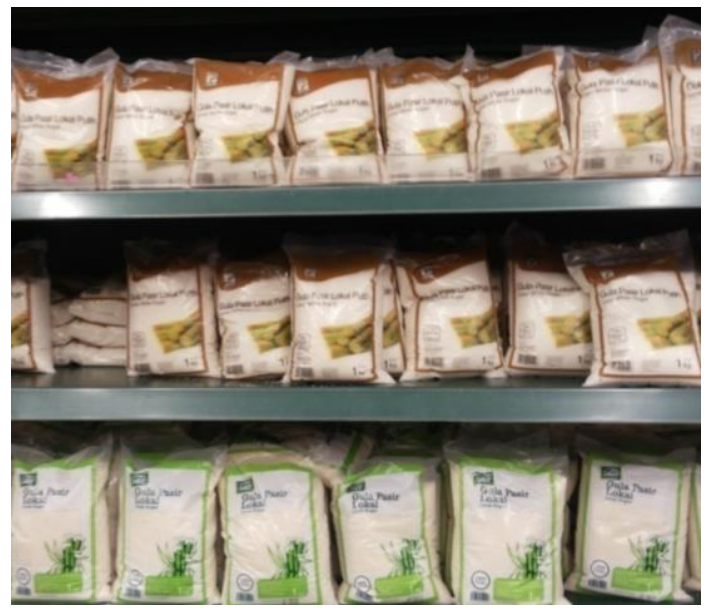

Gambar 4. Desain kemasan gula Save $L$ baru (atas) dan kemasan lama (bawah)

Berdasarkan hasil wawancara dengan Bapak Ruin Filino kemasan dari gula merek Save L ini sedang mengalami masa pergantian kemasan dimana kemasan lama memang diakui kurang menarik dan kurang mengundang perhatian konsumen yang melewati display gula pada Lotte Mart Festival City Link sehingga pihak Lotte Mart memutuskan untuk mengganti kemasan gula dengan merek Save $L$.
Tabel 2. Tabulasi Silang Karakteristik Konsumen dengan Preferensi Konsumen terhadap Atribut Desain Kemasan Produk Gula Private label

\begin{tabular}{|c|c|c|c|}
\hline \multirow{2}{*}{$\begin{array}{c}\text { Variabel } \\
\text { Karakteristik } \\
\text { Konsumen }\end{array}$} & \multicolumn{2}{|c|}{ Desain Kemasan } & \multirow[b]{2}{*}{ Total } \\
\hline & Menarik & $\begin{array}{c}\text { Tidak } \\
\text { Menarik }\end{array}$ & \\
\hline \multicolumn{4}{|l|}{ Jenis Kelamin } \\
\hline Laki-laki & 6 & 6 & 12 \\
\hline perempuan & 19 & 11 & 30 \\
\hline Total & 25 & 17 & 42 \\
\hline \multicolumn{4}{|l|}{ Usia } \\
\hline $19-24$ & 0 & 2 & 2 \\
\hline $25-35$ & 7 & 7 & 14 \\
\hline $36-50$ & 10 & 8 & 18 \\
\hline $51-65$ & 6 & 0 & 6 \\
\hline$>65$ & 2 & 0 & 2 \\
\hline Total & 25 & 17 & 42 \\
\hline \multicolumn{4}{|l|}{ Pendidikan } \\
\hline $\mathrm{SD}$ & 2 & 0 & 2 \\
\hline SMP & 6 & 0 & 6 \\
\hline SMA & 8 & 8 & 16 \\
\hline Diploma & 5 & 5 & 10 \\
\hline Sarjana & 4 & 4 & 8 \\
\hline Total & 25 & 17 & 42 \\
\hline \multicolumn{4}{|l|}{ Pekerjaan } \\
\hline $\begin{array}{l}\text { PNS/Pegawai } \\
\text { Swasta }\end{array}$ & 7 & 7 & 14 \\
\hline $\begin{array}{l}\text { Pelajar/ } \\
\text { Mahasiswa }\end{array}$ & 0 & 2 & 2 \\
\hline $\begin{array}{l}\text { Ibu Rumah } \\
\text { Tangga }\end{array}$ & 15 & 8 & 23 \\
\hline Lainnya & 3 & 0 & 3 \\
\hline Total & 25 & 17 & 42 \\
\hline \multicolumn{4}{|l|}{ Pendapatan } \\
\hline $\begin{array}{l}<\text { Rp. } \\
2.000 .000\end{array}$ & 2 & 2 & 4 \\
\hline $\begin{array}{l}\text { Rp. 2.000.000- } \\
\text { Rp. } 4.000 .000\end{array}$ & 20 & 13 & 33 \\
\hline $\begin{array}{l}>\mathrm{Rp} . \\
4.000 .000\end{array}$ & 3 & 2 & 5 \\
\hline Total & 25 & 17 & 42 \\
\hline
\end{tabular}

Hal tersebut juga berlaku untuk karakteristik konsumen pekerjaan dimana responden yang mengatakan desain kemasan ini menarik mayoritas bekerja sebagai ibu rumah tangga. Sedangkan responden yang mengatakan desain kemasan ini kurang menarik mayoritas 
bekerja sebagai pegawai swasta/PNS dan ibu rumah tangga. Para responden ini mengatakan bahwa menurut mereka lebih menarik produk pesaing yang menampilkan kemasan yang berbeda dari lainnya.

Pada persilangan antara karakteristik konsumen pendapatan dengan preferensi konsumen terhadap atribut desain kemasan responden dengan jawaban menarik berasal dari responden dengan pendapatan kurang dari $\mathrm{Rp}$ 2.000.000 sebanyak dua orang, Rp2.000.000-Rp4.000.000 sebanyak 20 orang, dan lebih dari Rp 4.000.000 sebanyak tiga orang. Sedangkan untuk jawaban kurang menarik didominasi oleh responden dengan pendapatan Rp2.000.000-Rp4.000.000 sebanyak 13 orang, kurang dari $\mathrm{Rp} \quad 2.000 .000$ sebanyak dua orang, dan lebih dari Rp 4.000.000 sebanyak dua orang.

\section{Kejelasan Informasi Produk Gula Private label}

Kejelasan informasi produk sangat penting keberadaannya, mengingat keamanan suatu produk makanan dan minuman harus diperiksa keamanannya (Sari dkk., 2020). Indonesia merupakan negara yang masyarakatnya sebagian besar memeluk agama Islam sehingga membutuhkan sertifikasi halal terhadap suatu produk makanan maupun minuman.

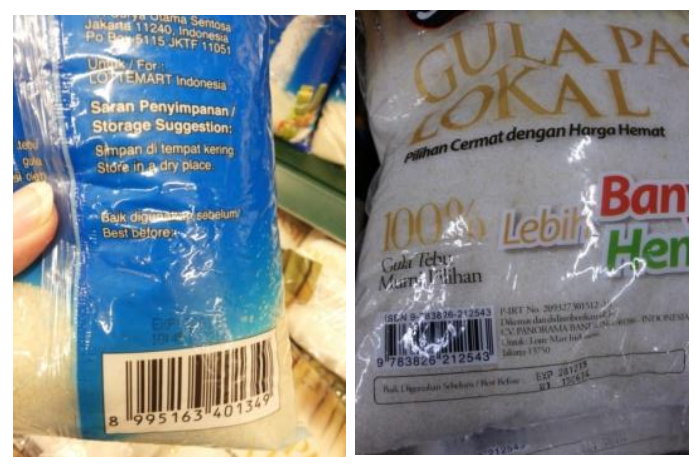

Gambar 5. Kejelasan informasi produk gula Choice L dan Jempol

Preferensi konsumen terhadap atribut kejelasan informasi produk dari gula private label, yaitu $83 \%$ konsumen gula private label menyatakan produk tersebut sudah jelas. Sedangkan sebanyak $17 \%$ konsumen menyatakan ketidakjelasan mengenai keterangan informasi pada produk seperti tanggal kadaluarsa dan sertifikasi halalnya tidak terpampang secara jelas pada kemasan.

Pada persilangan karakteristik jenis kelamin dengan atribut kejelasan informasi, responden dengan jawaban atribut informasi ini sudah jelas didominasi oleh responden perempuan dengan jumlah 28 orang dan laki-laki sebanyak tujuh orang. Sedangkan untuk jawaban atribut informasi tidak jelas didominasi oleh responden pria dengan jumlah lima orang dari total tujuh orang yang menjawab atribut informasi pada produk ini tidak jelas. Hal ini 
membuktikan bahwa responden laki-laki lebih memperhatikan hal-hal seperti ini dibanding responden perempuan. Menurut Kotler et al (2014), pria cenderung mengambil lebih banyak data di lingkungan mereka, hal ini menyebabkan perilaku antara laki-laki dan perempuan menjadi berbeda.

Pada hasil persilangan antara karakteristik konsumen usia dengan preferensi konsumen terhadap atribut kejelasan informasi, dapat dilihat pada Tabel 3. Pada tabel tersebut terlihat bahwa berdasarkan faktor usia secara keseluruhan responden yang menjawab informasi produk gula ini jelas adalah responden dengan usia 36-50 tahun. Sedangkan responden yang menjawab atribut informasi produk gula ini tidak jelas adalah responden dengan usia 25-35 tahun. Hal ini memperlihatkan bahwa pada usia tersebut merupakan kelompok usia yang lebih peka terhadap informasi dibanding kelompok usia lainnya.

Menurut hasil persilangan antara karakteristik konsumen pendidikan dengan preferensi konsumen terhadap atribut kejelasan informasi dapat dilihat bahwa responden dengan jawaban atribut informasi ini sudah jelas adalah responden dengan mayoritas pendidikan terakhir SMA sebanyak 16 orang, SD sebanyak dua orang, SMP sebanyak enam orang, Diploma sebanyak tujuh orang, Sarjana sebanyak empat orang.

Sedangkan responden yang menjawab informasi produk ini tidak jelas adalah responden dengan tingkat pendidikan Diploma dan Sarjana yang masing-masing berjumlah tiga dan empat orang. Para konsumen menegaskan bahwa informasi kejelasan produk seperti tanggal kadaluarsa dan sertifikasi halal sangat penting karena itu merupakan hal yang mendasar yang harus ada pada suatu produk sehingga harus diperhatikan karena menyangkut keamanan dan kenyamanan konsumen dalam mengkonsumsi suatu produk.

Hal ini memperlihatkan tingkat pendidikan seseorang membedakan mereka dalam hal memilih suatu barang berdasarkan manfaat yang akan didapat. Menurut Rasmikayati dkk. (2017) Pengetahuan terhadap produk mencakup kesadaran akan kategori dan merek produk, terminologi produk, atribut dan ciri produk serta pengetahuan harga.

Pada hasil persilangan antara karakteristik konsumen pekerjaan dengan preferensi konsumen terhadap atribut kejelasan informasi dapat dilihat bahwa responden dengan jawaban atribut informasi ini sudah jelas adalah 
responden dengan pekerjaan sebagai ibu rumah tangga sebanyak 22 orang, PNS/Pegawai swasta sebanyak delapan orang, pelajar/mahasiswa sebanyak dua orang, dan tiga orang merupakan pensiunan dan wirausaha.

Tabel 3. Tabulasi Silang Karakteristik Konsumen dengan Preferensi Konsumen terhadap Atribut Kejelasan Informasi Produk Gula Private label

\begin{tabular}{|c|c|c|c|}
\hline \multirow{2}{*}{$\begin{array}{c}\text { Variabel Karakteristik } \\
\text { Konsumen }\end{array}$} & \multicolumn{2}{|c|}{$\begin{array}{l}\text { Kejelasan } \\
\text { Informasi }\end{array}$} & \multirow{2}{*}{ Tota } \\
\hline & Jelas & $\begin{array}{l}\text { Tidak } \\
\text { Jelas }\end{array}$ & \\
\hline \multicolumn{4}{|l|}{ Jenis Kelamin } \\
\hline Laki-laki & 7 & 5 & 12 \\
\hline perempuan & 28 & 2 & 30 \\
\hline Total & 35 & 7 & 42 \\
\hline \multicolumn{4}{|l|}{ Usia } \\
\hline $19-24$ & 2 & 0 & 2 \\
\hline $25-35$ & 8 & 6 & 14 \\
\hline $36-50$ & 17 & 1 & 18 \\
\hline $51-65$ & 6 & 0 & 6 \\
\hline$>65$ & 2 & 0 & 2 \\
\hline Total & 35 & 7 & 42 \\
\hline \multicolumn{4}{|l|}{ Pendidikan } \\
\hline $\mathrm{SD}$ & 2 & 0 & 2 \\
\hline SMP & 6 & 0 & 6 \\
\hline SMA & 16 & 0 & 16 \\
\hline Diploma & 7 & 3 & 10 \\
\hline Sarjana & 4 & 4 & 8 \\
\hline Total & 35 & 7 & 42 \\
\hline \multicolumn{4}{|l|}{ Pekerjaan } \\
\hline PNS/Pegawai Swasta & 8 & 6 & 14 \\
\hline Pelajar/Mahasiswa & 2 & 0 & 2 \\
\hline Ibu Rumah Tangga & 22 & 1 & 23 \\
\hline Lainnya & 3 & 0 & 3 \\
\hline Total & 35 & 7 & 42 \\
\hline \multicolumn{4}{|l|}{ Pendapatan } \\
\hline$<$ Rp. 2.000.000 & 4 & 0 & 4 \\
\hline $\begin{array}{l}\text { Rp. 2.000.000-Rp. } \\
4.000 .000\end{array}$ & 27 & 6 & 33 \\
\hline > Rp. 4.000.000 & 4 & 1 & 5 \\
\hline Total & 35 & 7 & 42 \\
\hline
\end{tabular}

Sedangkan responden yang menjawab informasi produk ini tidak jelas adalah responden dengan status pekerjaan PNS/pegawai swasta sebanyak enam orang dan ibu rumah tangga sebanyak satu orang. Dimana dalam hal ini berkaitan dengan karakteristik pendidikan yang telah dijelaskan sebelumnya, bahwa sebagian besar responden dengan status pekerjaan PNS/pegawai swasta ini merupakan responden dengan pendidikan terakhir Diploma dan Sarjana.

Kejelasan informasi produk sangat penting keberadaannya, Indonesia merupakan negara yang masyarakatnya sebagian besar memeluk agama Islam sehingga membutuhkan sertifikasi halal terhadap suatu produk makanan maupun minuman.

$$
\text { Pada persilangan antara }
$$
karakteristik pendapatan dengan atribut kejelasan informasi dapat dilihat bahwa mayoritas konsumen yang menjawab atribut informasi ini jelas merupakan responden dengan penghasilan Rp2.000.000-Rp4.000.000 sebanyak 27 orang, dan sisanya merupakan responden dengan pendapatan kurang dari $\mathrm{Rp}$ 2.000.000 sebanyak empat orang dan lebih dari Rp 4.000.000 sebanyak empat orang juga. Responden yang menyatakan atribut produk ini tidak jelas berasal dari konsumen dengan pendapatan $\mathrm{Rp}$ 2.000.000-Rp. 4.000.000 sebanyak enam 
orang dan satu orang merupakan responden dengan pendapatan diatas $\mathrm{Rp}$ 4.000.000.

\section{Kemudahan dalam Memperoleh}

\section{Produk Gula Private label}

Kemudahan memperoleh produk merupakan suatu pelayanan dari produsen dan juga distributor kepada konsumen (Rasmikayati dkk., 2020). Semakin banyaknya produk ditemukan oleh konsumen maka semakin banyak peluang produk tersebut dibeli oleh konsumen. Menurut hasil persilangan antara karakteristik konsumen dengan preferensi konsumen terhadap atribut kemudahan memperoleh produk yang terdapat pada Tabel 4 dapat dilihat bahwa respon konsumen terhadap atribut ini sudah sangat baik.

Pada Tabel 4 dapat dilihat bahwa 42 responden menjawab produk gula private label ini mudah didapatkan. Persediaan barang ini berkaitan dengan pendistribusian yang dilakukan oleh pihak Lotte Mart. Keputusan Lotte Mart untuk bekerja sama dengan supplier local sangat membantu dalam mengatur persediaan barang produk gula private label ini. Responden dengan berbagai macam karakter menganggap bahwa kemudahan memperoleh produk ini penting karena menurut salah seorang responden jika dirinya mudah mendapatkan sebuah produk maka dia akan mengulang lagi pembelian tersebut.

Tabel 4. Tabulasi Silang Karakteristik Konsumen dengan Preferensi Konsumen terhadap Atribut Kemudahan Memperoleh Produk Gula Private label

\begin{tabular}{|c|c|c|c|}
\hline \multirow{2}{*}{$\begin{array}{c}\text { Variabel } \\
\text { Karakteristik } \\
\text { Konsumen }\end{array}$} & \multicolumn{2}{|c|}{$\begin{array}{l}\text { Kemudahan } \\
\text { Memperoleh }\end{array}$} & \multirow{2}{*}{ Total } \\
\hline & Mudah & $\begin{array}{l}\text { Tidak } \\
\text { Mudah }\end{array}$ & \\
\hline \multicolumn{4}{|l|}{ Jenis Kelamin } \\
\hline Laki-laki & 12 & 0 & 12 \\
\hline perempuan & 30 & 0 & 30 \\
\hline Total & 42 & 0 & 42 \\
\hline \multicolumn{4}{|l|}{ Usia } \\
\hline $19-24$ & 2 & 0 & 2 \\
\hline $25-35$ & 14 & 0 & 14 \\
\hline $36-50$ & 18 & 0 & 18 \\
\hline $51-65$ & 6 & 0 & 6 \\
\hline$>65$ & 2 & 0 & 2 \\
\hline Total & 42 & 0 & 42 \\
\hline \multicolumn{4}{|l|}{ Pendidikan } \\
\hline $\mathrm{SD}$ & 2 & 0 & 2 \\
\hline SMP & 6 & 0 & 6 \\
\hline SMA & 16 & 0 & 16 \\
\hline Diploma & 10 & 0 & 10 \\
\hline Sarjana & 8 & 0 & 8 \\
\hline Total & 42 & 0 & 42 \\
\hline \multicolumn{4}{|l|}{ Pekerjaan } \\
\hline PNS/Pegawai & 14 & 0 & 14 \\
\hline Swasta & & & \\
\hline Pelajar/Mahasiswa & 2 & 0 & 2 \\
\hline Ibu Rumah Tangga & 23 & 0 & 23 \\
\hline Lainnya & 3 & 0 & 3 \\
\hline Total & 42 & 0 & 42 \\
\hline \multicolumn{4}{|l|}{ Pendapatan } \\
\hline < Rp. 2.000.000 & 4 & 0 & 4 \\
\hline $\begin{array}{l}\text { Rp. 2.000.000-Rp. } \\
4.000 .000\end{array}$ & 33 & 0 & 33 \\
\hline$>$ Rp. 4.000 .000 & 5 & 0 & 5 \\
\hline Total & 42 & 0 & 42 \\
\hline
\end{tabular}

Sumber: Data Primer (Diolah, 2020)

Para konsumen yang menjadi responden peneliti menganggap produk gula private label ini mudah didapatkan karena selalu ada dan tidak pernah kehabisan. Selain itu, pihak Lotte Mart 
juga menempatkan produk gula private label ini ditempat yang mudah ditemukan.

\section{Harga Gula Private label}

Harga merupakan ukuran kemampuan seseorang untuk membeli sebuah produk dengan uang yang dimilikinya (Natawidjaja dkk., 2017). Harga yang ditawarkan oleh masingmasing produsen ditawarkan berbedabeda meski dengan produk yang sejenis, hal ini disebabkan adanya perbedaan kualitas dan brand image dari produk itu sendiri. Menurut hasil wawancara dapat terlihat preferensi konsumen terhadap harga dari gula private label, sebanyak $100 \%$ mengatakan harga gula tidak mahal dan tidak ada yang menjawab bahwa harga gula tersebut mahal.

Berdasarkan perhitungan tabulasi silang antara karakteristik dengan preferensi konsumen terhadap atribut harga pada Tabel 5 dapat dilihat bahwa Lotte Mart berhasil membuat produk gula private label ini dapat dinikmati oleh semua kalangan. Terlihat pada Tabel 5 dimana seluruh responden berjenis kelamin laki-laki sebanyak 12 orang serta responden perempuan sebanyak 30 orang mengatakan bahwa atribut harga dari produk gula private label ini murah.
Tabel 5. Tabulasi Silang Karakteristik Konsumen dengan Preferensi Konsumen terhadap Atribut Harga Produk Gula Private label

\begin{tabular}{|c|c|c|c|}
\hline \multirow{2}{*}{$\begin{array}{c}\text { Variabel } \\
\text { Karakteristik } \\
\text { Konsumen }\end{array}$} & \multicolumn{2}{|c|}{ Harga } & \multirow[b]{2}{*}{ Total } \\
\hline & Murah & $\begin{array}{l}\text { Tidak } \\
\text { Murah }\end{array}$ & \\
\hline \multicolumn{4}{|l|}{ Jenis Kelamin } \\
\hline Laki-laki & 12 & 0 & 12 \\
\hline perempuan & 30 & 0 & 30 \\
\hline Total & 42 & 0 & 42 \\
\hline \multicolumn{4}{|l|}{ Usia } \\
\hline $19-24$ & 2 & 0 & 2 \\
\hline $25-35$ & 14 & 0 & 14 \\
\hline $36-50$ & 18 & 0 & 18 \\
\hline $51-65$ & 6 & 0 & 6 \\
\hline$>65$ & 2 & 0 & 2 \\
\hline Total & 42 & 0 & 42 \\
\hline \multicolumn{4}{|l|}{ Pendidikan } \\
\hline $\mathrm{SD}$ & 2 & 0 & 2 \\
\hline SMP & 6 & 0 & 6 \\
\hline SMA & 16 & 0 & 16 \\
\hline Diploma & 10 & 0 & 10 \\
\hline Sarjana & 8 & 0 & 8 \\
\hline Total & 42 & 0 & 42 \\
\hline \multicolumn{4}{|l|}{ Pekerjaan } \\
\hline PNS/Pegawai Swasta & 14 & 0 & 14 \\
\hline Pelajar/Mahasiswa & 2 & 0 & 2 \\
\hline Ibu Rumah Tangga & 23 & 0 & 23 \\
\hline Lainnya & 3 & 0 & 3 \\
\hline Total & 42 & 0 & 42 \\
\hline \multicolumn{4}{|l|}{ Pendapatan } \\
\hline$<$ Rp. 2.000 .000 & 4 & 0 & 4 \\
\hline $\begin{array}{l}\text { Rp. 2.000.000-Rp. } \\
4.000 .000\end{array}$ & 33 & 0 & 33 \\
\hline > Rp. 4.000.000 & 5 & 0 & 5 \\
\hline Total & 42 & 0 & 42 \\
\hline
\end{tabular}

Sumber: Data Primer (Diolah, 2020)

Pada Tabel 5 dapat kita lihat hasil persilangan antara karakteristik konsumen usia dengan preferensi konsumen terhadap atribut harga, dimana seluruh golongan usia pada penelitian ini menjawab bahwa harga dari produk ini murah dan sudah terjangkau. Begitu pula dengan persilangan antara karakteristik konsumen pekerjaan dengan atribut 
harga, seluruh responden dengan berbagai macam pekerjaan seperti PNS/pegawai swasta, pelajar/mahasiswa, ibu rumah tangga, pensiunan dan wirausaha menyatakan hal yang sama. Serta apabila melihat dari hasil pendapatan konsumen yang diterima dapat disimpulkan bahwa produk gula private label ini memang ditargetkan dapat dinikmati oleh semua golongan.

Menurut hasil persilangan dapat dikatakan bahwa seluruh responden baik yang muda, tua, perempuan, laki-laki, dan dari golongan pekerjaan manapun bisa dikatakan menginginkan suatu produk yang dapat dinikmati dengan harga yang murah. Terlebih lagi telah dikatakan sebelumnya bahwa beberapa responden sudah mengetahui bahwa produk gula private label ini memang menggunakan kualitas bahan yang sama dengan national brand.

\section{Kualitas Pelayanan Lotte Mart Festival City Link}

Preferensi konsumen terhadap kualitas pelayanan dari gula private label. Konsumen sebanyak 69\% menyatakan bahwa kualitas pelayanan dari Lotte Mart Festival City Link ini sudah memuaskan. Sedangkan sebanyak $31 \%$ konsumen menyatakan kualitas pelayanan Lotte Mart kurang baik.
Tabel 6. Tabulasi Silang Karakteristik Konsumen dengan Preferensi Konsumen terhadap Atribut Kualitas Pelayanan Lotte Mart Festival City Link

\begin{tabular}{|c|c|c|c|}
\hline \multirow{2}{*}{$\begin{array}{c}\text { Variabel Karakteristik } \\
\text { Konsumen }\end{array}$} & \multicolumn{2}{|c|}{$\begin{array}{c}\text { Kualitas } \\
\text { Pelayanan }\end{array}$} & \multirow{2}{*}{ Tota } \\
\hline & Baik & $\begin{array}{l}\text { Tidak } \\
\text { Baik } \\
\end{array}$ & \\
\hline \multicolumn{4}{|l|}{ Jenis Kelamin } \\
\hline Laki-laki & 9 & 3 & 12 \\
\hline perempuan & 20 & 10 & 30 \\
\hline Total & 29 & 13 & 42 \\
\hline \multicolumn{4}{|l|}{ Usia } \\
\hline $19-24$ & 1 & 1 & 2 \\
\hline $25-35$ & 5 & 9 & 14 \\
\hline $36-50$ & 15 & 3 & 18 \\
\hline $51-65$ & 6 & 0 & 6 \\
\hline$>65$ & 2 & 0 & 2 \\
\hline Total & 29 & 13 & 42 \\
\hline \multicolumn{4}{|l|}{ Pendidikan } \\
\hline $\mathrm{SD}$ & 2 & 0 & 2 \\
\hline SMP & 6 & 0 & 6 \\
\hline SMA & 14 & 2 & 16 \\
\hline Diploma & 5 & 5 & 10 \\
\hline Sarjana & 2 & 6 & 8 \\
\hline Total & 29 & 13 & 42 \\
\hline \multicolumn{4}{|l|}{ Pekerjaan } \\
\hline PNS/Pegawai Swasta & 7 & 7 & 14 \\
\hline Pelajar/Mahasiswa & 1 & 1 & 2 \\
\hline Ibu Rumah Tangga & 18 & 5 & 23 \\
\hline Lainnya & 3 & 0 & 3 \\
\hline Total & 29 & 13 & 42 \\
\hline \multicolumn{4}{|l|}{ Pendapatan } \\
\hline$<$ Rp. 2.000.000 & 3 & 1 & 4 \\
\hline $\begin{array}{l}\text { Rp. } 2.000 .000-R p . \\
4.000 .000\end{array}$ & 22 & 11 & 33 \\
\hline > Rp. 4.000 .000 & 4 & 1 & 5 \\
\hline Total & 29 & 13 & 42 \\
\hline
\end{tabular}

Sumber: Data Primer (Diolah, 2020)

Menurut hasil persilangan antara karakteristik konsumen jenis kelamin dengan preferensi konsumen terhadap atribut kualitas pelayanan, responden yang menjawab bahwa kualitas pelayanan dari Lotte Mart ini sudah baik adalah sebanyak 29 orang terdiri atas sembilan oang responden laki-laki dan 20 orang responden perempuan. Sisanya 
yaitu sebanyak tiga orang responden lakilaki dan sepuluh orang responden perempuan mengatakan kurang puas dengan pelayanan yang diberikan oleh Lotte Mart Festival City Link.

Para responden berjenis kelamin perempuan yang menjawab puas dengan pelayanan Lotte Mart memiliki alasan yang beragam, salah satunya mengatakan bahwa mereka cukup puas dengan pelayanan para staf dan menurut mereka para karyawan di Lotte Mart ini sudah sangat kooperatif atau mau membantu mereka bila kesulitan dalam berbelanja misalkan terdapat beberapa produk yang tidak tercantum harganya maka karyawan langsung sigap menanganinya.

Akan tetapi, hal ini berlawanan dengan responden laki-laki dan perempuan yang menyatakan kurang puas dengan kualitas pelayanan yang diberikan mereka menyatakan bahwa terdapat beberapa hal yang mereka kurang sukai salah satunya adalah kecepatan karyawan di meja information centre atau pusat pelayanan. Dimana pada meja tersebut pelanggan dapat menukar poin undian dan menitipkan barang yang tidak diperkenankan dibawa masuk ke dalam wilayah Lotte Mart.

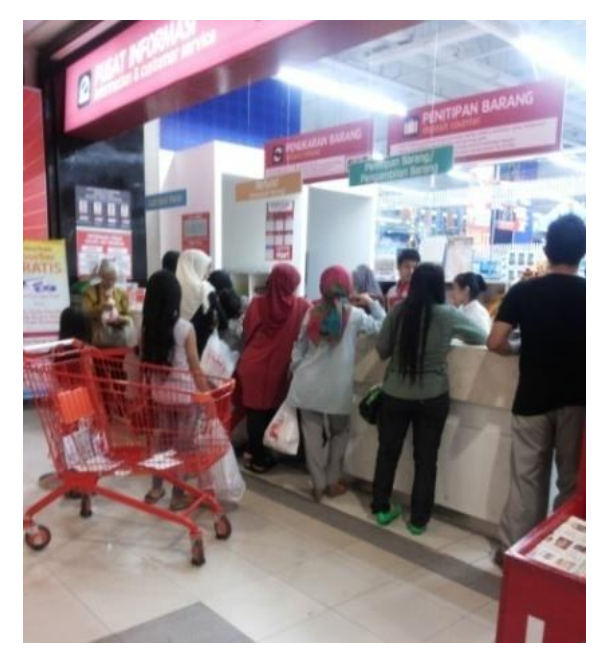

Gambar 6. Meja pusat pelayanan atau information centre yang selalu ramai

Mereka menyatakan kurang suka dengan pelayanan yang lamban sehingga mereka harus menghabiskan waktu lebih lama untuk mengantri menitipkan barang, terutama di jam-jam padat pengunjung seperti waktu peneliti mewawancara yaitu sekitar jam 19.00 pada hari Sabtu.

Menurut persilangan antara karakteristik konsumen usia dengan atribut kualitas pelayanan ini mayoritas responden yang menjawab kualitas pelayanan Lotte Mart baik adalah responden yang berusia 36-50 tahun sebanyak 15 orang, 19-24 tahun sebanyak satu orang, 25-35 tahun sebanyak lima orang, usia 51-65 tahun sebanyuak enam orang, lebih dari 65 tahun sebanyak dua orang. Sedangkan responden yang usianya 25-35 tahun sebanyak sembilan orang, usia 19-24 tahun satu orang, usia 36-50 sebanyak tiga orang menyatakan 
mereka kurang puas dengan pelayanannya.
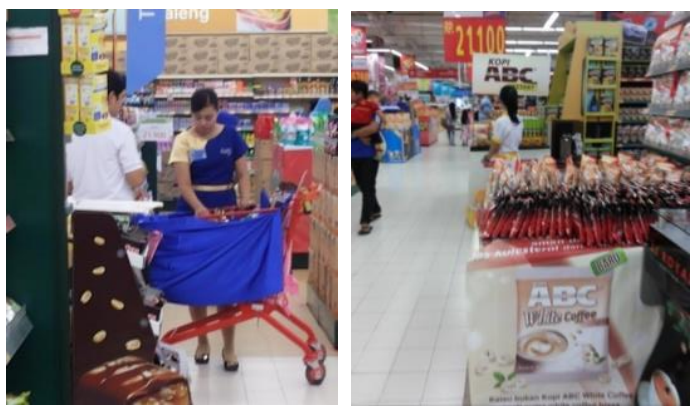

Gambar 7. Kehadiran beberapa SPG di Lotte Mart Festival City Link

Para responden yang kebanyakan berusia muda ini menyatakan bahwa mereka kurang nyaman dengan kehadiran banyak Sales Promotion Girl (SPG) yang sering sedikit memaksa mereka untuk membeli atau sekedar mencoba produk yang sedang ditawarkan atau apabila terdapat event promosi dari produk tertentu.

$\begin{array}{crr}\text { Pada } & \text { persilangan } & \text { antara } \\ \text { karakteristik } & \text { konsumen } & \text { tingkat }\end{array}$
pendidikan dengan atribut pelayanan kualitas mayoritas responden yang menjawab puas dengan pelayanan Lotte Mart adalah responden dengan tingkat pendidikan SMA sebanyak 14 orang, SD dua orang, SMP enam orang, Diploma sebanyak lima orang, dan Sarjana sebanyak dua orang.

Responden dengan jawaban kurang puas lebih didominasi oleh responden dengan tingkat pendidikan akhir Diploma dan Sarjana masing-masing sebanyak lima dan enam orang, sisanya merupakan responden dengan tingkat pendidikan SMA sebanyak dua orang. Dalam hal ini bisa dikatakan bahwa tinggi rendahnya tingkat pendidikan seseorang akan mempengaruhi caranya menilai sesuatu yang dirasakan.

Pada karakteristik pekerjaan, dimana responden yang kurang puas dengan pelayanan Lotte Mart merupakan konsumen dengan status pekerjaan PNS/pegawai swasta dengan jumlah sebanyak tujuh orang, pelajar/mahasiswa sebanyak satu orang dan ibu rumah tangga sebanyak lima orang. Sedangkan untuk responden yang puas didominasi oleh responden dengan status pekerjaan ibu rumah tangga sebanyak 18 orang, pelajar/mahasiswa sebanyak satu orang, PNS/pegawai swasta sebanyak tujuh orang, dan pekerjaan lainnya sebanyak tiga orang.

Pada karakteristik pendapatan, dimana responden yang puas dengan pelayanan Lotte Mart merupakan konsumen dengan pendapatan $\mathrm{Rp}$ 2.000.000-Rp. 4.000 .000 sebanyak 22 orang, kurang dari $\mathrm{Rp} \quad 2.000 .000$ sebanyak tiga orang dan lebih dari $\mathrm{Rp}$ 4.000.000 sebanyak empat orang. Sedangkan responden yang menyatakan 
tidak puas dengan pelayanan Lotte Mart merupakan responden dengan pendapatan Rp 2.000.000-Rp 4.000.000 sebanyak sebelas orang, kurang dari Rp 2.000.000 sebanyak satu orang dan lebih dari $\mathrm{Rp}$ 4.000.000 juga sebanyak satu orang.

Menurut Amridha dkk. (2020), tingkat pendidikan, jenis pekerjaan, dan jumlah pendapatan merupakan suatu hal yang berkaitan sehingga mempengaruhi cara bertindak dan berpikir seorang konsumen. Terdapat beberapa responden yang menyatakan bahwa kasir/tempat pembayaran jalur cepat (fast track) terlalu sedikit sehingga mengakibatkan konsumen yang tidak membeli banyak harus menunggu lama, sedangkan jika ingin mengantri di kasir lain konsumen harus mengantri lebih lama karena banyak orang yang belanja sampai satu troli penuh.

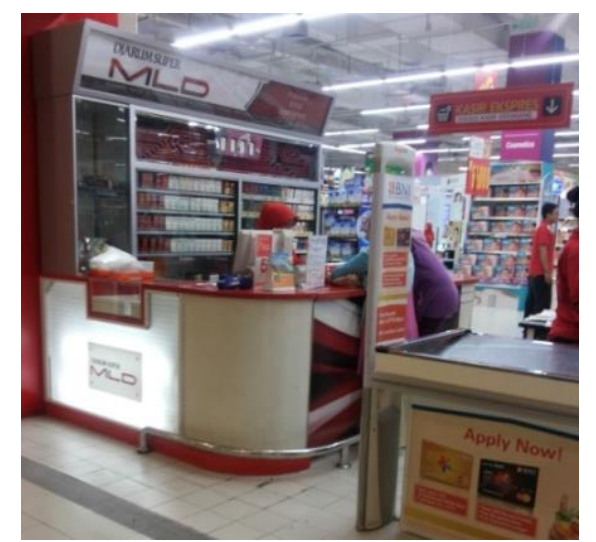

Gambar 8. Kasir fast track di Lotte Mart Festival City Link
Hal ini sesuai dengan lima dimensi karakteristik yang digunakan oleh para pelanggan dalam mengevaluasi kualitas pelayanan yang dikemukakan Saefudin dkk. (2020) dimana dalam hal ini para konsumen menilai kepuasan mereka dari segi reliability (kehandalan) dalam hal ini beberapa konsumen yang mengaku kurang puas menyatakan pelayanan pada meja information centre kurang sigap dan hanya ada satu kasir jalur cepat, responsiveness (daya tangkap) dimana terdapat beberapa staf yang kurang paham atau tidak dapat membantu konsumen ketika menghadapi sebuah masalah ketika berbelanja, dan assurance (jaminan) dimana konsumen mengaku tidak nyaman dengan keberadaan SPG yang kadang memaksa untuk menawarkan produknya.

\section{KESIMPULAN DAN SARAN}

Pada preferensi konsumen ukuran yang paling ideal menurut para responden adalah ukuran gula sebesar $1 \mathrm{~kg}$, desain kemasan gula private label sudah dikatakan menarik untuk merek Choice $L$, kejelasan informasi yang ada masih dikatakan kurang jelas dikarenakan informasi tentang produk tidak diperlihatkan secara jelas sehingga harus benar-benar memperhatikan kemasan dari 
produk tersebut. Atribut harga dan kemudahan dalam memperoleh produk gula merupakan faktor utama konsumen membeli produk gula dengan private label ini. Konsumen yang memiliki preferensi baik terhadap privat label gula umumnya berjenis kelamin perempuan, berusia 36-50 tahun, berpendidikan SMA, pekerjaan sebagai ibu rumah tangga dengan pendapatan Rp 2.000.000Rp 4.000.000 per bulan.

Pihak perusahaan diharapkan dapat meminimalisir kekurangan pada produk gula private label diantaranya produk gula bermerek Jempol agar lebih fokus dijual pada Lotte Mart yang bergerai wholesale, dimana ukuran yang sebesar 3 kg tersebut tidak cocok dijual di Lotte Mart dengan gerai hypermarket seperti di Lotte Mart Festival City Link, membuat desain kemasan produk menjadi lebih menarik dengan menambah warna serta menambah corak yang dapat menarik minat konsumen dari berbagai golongan. Selain itu, peneliti menyarankan menambah kejelasan informasi halal pada produk sehingga konsumen tidak khawatir mengkonsumsi produk tersebut.

\section{DAFTAR PUSTAKA}

Abdullah, R. B., Ismail, N. B., Rahman, A. F. B. A., Suhaimin, M. B. M., Safie, S. K. B., Tajuddin, M. T. H.
M., ... \& Nair, G. K. S. (2012). The relationship between store brand and customer loyalty in retailing in Malaysia. Asian Social Science, 8(2), 171.

Amridha, Y., Heryanto, M. A., Saefudin, B. R., \& Awaliyah, F. (2020). The Analysis of The Employee's Job Satisfaction and Performance In Private Agricultural Company. Mahatani: Jurnal Agribisnis (Agribusiness and Agricultural Economics Journal), 2(2).

Daryanto, D. (2011). Sari Kuliah Manajemen Pemasaran. Bandung: PT Sarana Tutorial Nurani Sejahtera.

Deaniera, A. N., Rasmikayati, E., Saefudin, B. R., Supyandi, D., \& Sukayat, Y. (2020). Studi Komparatif Proses Bisnis Usaha Jigana Coffee Shop Dan Kedai Kopi Inspirasi Cibinong, Kabupaten Bogor.

Kotler, P., \& Armstrong, G. (2008). Prinsip-prinsip Pemasaran, jilid 1. Jakarta: erlangga.

Kotler, P., Keller, K. L., Ancarani, F., \& Costabile, M. (2014). Marketing management 14/e. Pearson.

Natawidjaja, R. S., Sulistiowaty, L., Kusno, K., Aryani, D., \& Rachmat, B. (2017). Analisis Preferensi, Kepuasan, dan Kesediaan Konsumen Membayar Beras Di Kota Bandung.

Peter, J. P., \& Olson, J. C. (2014). Consumer Behavior \& Marketing Strategy, trans. Diah Tantri Dwiandani, Consumer Behavior \& Marketing Strategies. Jakarta: Sal Empat Empat.

Rasmikayati, E., Afriyanti, S., \& Saefudin, B. R. (2020). Keragaan, Potensi dan Kendala pada Usaha Kedai Kopi Di Jatinangor: Kasus pada Belike Coffee Shop dan Balad Coffee Works. Agritekh (Jurnal 
Agribisnis dan Teknologi Pangan), 1(01), 26-45.

Rasmikayati, E., Deaniera, A. N., Supyandi, D., Sukayat, Y., \& Saefudin, B. R. (2020). Analisis Perilaku Konsumen: Pola Pembelian Kopi Serta Preferensi, Kepuasan Dan Loyalitas Konsumen Kedai Kopi. Mimbar Agribisnis: Jurnal Pemikiran Masyarakat Ilmiah Berwawasan Agribisnis, 6(2), 969-984.

Rasmikayati, E., Pardian, P., Hapsari, H., Ikhsan, R. M., \& Saefudin, B. R. (2017). Kajian Sikap dan Perilaku Konsumen dalam Pembelian Kopi Serta Pendapatnya Terhadap Varian Produk Dan Potensi Kedainya. Mimbar Agribisnis: Jurnal Pemikiran Masyarakat Ilmiah Berwawasan Agribisnis, 3(2), 117133.

Rasmikayati, E., Saefudin, B. R., Karyani, T., Kusno, K., \& Rizkiansyah, R. (2020). Analisis Faktor dan Tingkat Kepuasan Ditinjau dari Kualitas Produk dan Pelayanan pada Konsumen Sayuran Organik Di Lotte Mart Kota Bandung. Mimbar Agribisnis: Jurnal Pemikiran Masyarakat Ilmiah Berwawasan Agribisnis, 6(1), 351-364.
Rasmikayati, E., Shafira, N. A., Fauziah, Y. D., Ishmah, H. A. N., Saefudin, B. R., \& Utami, K. (2020). Keterkaitan antara Karakteristik Konsumen dengan Tingkat Kepuasan Mereka dalam Melakukan Pembelian Sayuran Organik. Agricore: Jurnal Agribisnis dan Sosial Ekonomi Pertanian Unpad, 5(1).

Saefudin, B. R., Deanier, A. N., \& Rasmikayati, E. (2020). Kajian Pembandingan Preferensi Konsumen pada Dua Kedai Kopi di Cibinong, Kabupaten Bogor. Agrovital: Jurnal Ilmu Pertanian, 5(1), 39-46.

Sari, Y., Rasmikayati, E., Saefudin, B. R., Karyani, T., \& Wiyono, S. N. (2020, March). Willingness To Pay Konsumen Beras Organik Dan Faktor-Faktor Yang Berkaitan Dengan Kesediaan Konsumen Untuk Membayar Lebih. In Forum Agribisnis (Vol. 10, No. 1, pp. 4657).

Sugiyono, S. (2010). Metode penelitian kuantitatif dan kualitatif dan R\&D. 